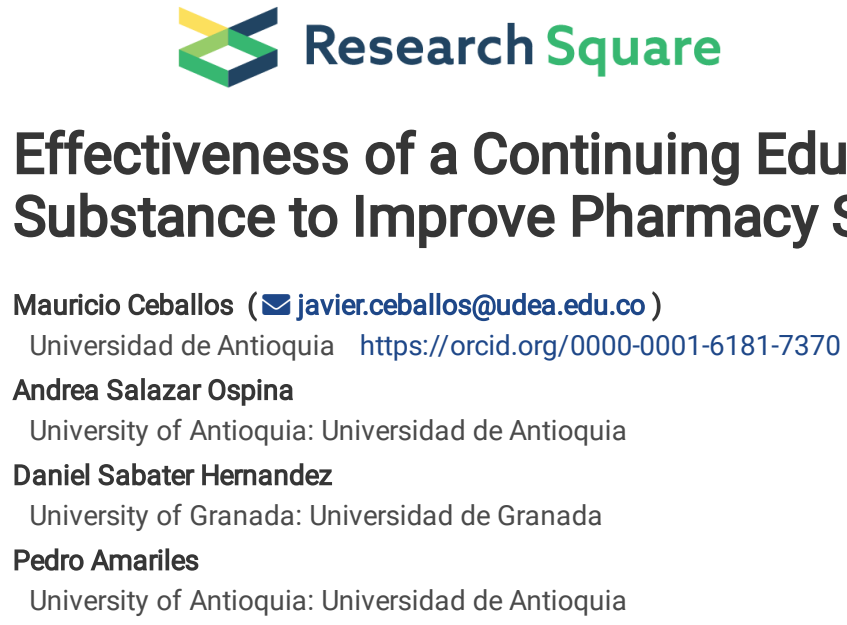

\title{
Effectiveness of a Continuing Education Program of Drugs with Fiscalized Substance to Improve Pharmacy Staff Competencies.
}

\section{Research Article}

Keywords: Dispensation, Health Education, Pharmacovigilance, Pharmacies, Pharmacy Staff, Fiscalized Substances.

Posted Date: May 17th, 2021

DOI: https://doi.org/10.21203/rs.3.rs-506700/v1

License: (9) (1) This work is licensed under a Creative Commons Attribution 4.0 International License. Read Full License 


\section{Abstract}

Background: The use of drugs with fiscalized substances without a correct prescription and without ambulatory pharmacy services can have negative consequences for public health.

Objectives: To evaluate the effectiveness of a continuing education program in drugstores and pharmacies that improves pharmacy staff competencies to provide ambulatory pharmacy services.

Setting: Ambulatory retail establishments (drugstores and pharmacies) in Colombia.

Method: A multicenter, prospective, parallel-group, cluster-randomized, controlled clinical trial was conducted. The intervention group (IG) received a continuing education program for 12 months, including web-based social networking sites with a virtual classroom, a virtual course composed of 7 modules, access to a drug and dispensing information system, and pharmacy staff training. Control group (CG) received written material on the correct use of complex dosage forms for 12 months.

Main outcome measure: Pharmacy staff competencies (knowledge, skills, and attitudes).

Results: The sample was 305 drugstores and pharmacies, 153 in the IG and 152 in the CG. Of the 750-pharmacy staff invited, 88\% (659) agreed to participate; a total of 379 pharmacy staff were assigned to the IG and 280 to the CG. Of a total, $65.3 \%$ (430) were women with a mean age was 35.6 years. At the end of the study, in the IG was statistically significant differences $(p<0.05)$ in the 25 skills and attitudes self-reported, also knowledge improved in six of the seven assessed modules.

Conclusion: Providing a continuing education program using various educational and active participation strategies improves assessed knowledge and selfreported for the provision of ambulatory pharmacy services.

\section{Impacts On Practice}

- Pharmacy staff needs to improve their required competencies to contribute to provision of ambulatory pharmacy services: dispensing, health education, and pharmacovigilance, minimizing medication errors and improving the adherence therapy.

- Implementing a continuing education program to pharmacy staff by integrating different methods and tools supported by Information and Communication Technologies (ICT) could favor access to relevant and quality information on health promotion, disease prevention, and the rational use of drugs with fiscalized substances (including controlled drugs).

- The pharmacy staff competencies refer to behavior that brings together different knowledge, skills, and attitudes that determine the achievement, dominance, or fulfillment of the competence in a real work environment, which can be evaluated based on the combination of research techniques.

\section{Introduction}

The pharmacy staff may encounter problems in the drugs' processes and results during the actual practice. Therefore, they must improve the correct use of drugs, minimizing medication errors and helping outpatients to better use their drug therapy. Pharmacy staff requires training, qualification, and continuing education through formal and non-formal education programs, focused on their competencies [1]. Competencies are the knowledge, skills, and attitudes that human talent in health requires in the different areas of practice to solve health problems efficiently and effectively, and it could be achieved through education, training, and experience [2]. Continuing education and communication with other health professionals are key to achieving optimal medication management in all phases or processes associated with drug utilization [3].

Worldwide there is evidence on the effectiveness and relevance of pharmaceutical interventions combined with Information and Communication Technologies (ICT), continuing education programs, and network support among pharmacy staff and other health professionals using drugs with fiscalized substances [47]. Medications with controlled substances, such as benzodiazepines, tricyclic antidepressants, anxiolytics, antipsychotics, opioid analgesics, are essential for the management and treatment of pain, obstetric emergencies, mental disorders and Drug Dependent Substances. Fiscalized substances are regulated by international conventions on drug control, recognizing their potential to be misused and cause harm, such as dependency syndrome and health disorders [8]. Furthermore, there are failures in the surveillance and control of the processes of these drugs; for instance, worldwide, including Colombia, it is common for many prescription medications to be dispensed without a valid medical prescription, even when one is required [9-10].

In the Colombian context [9], the drugstores and pharmacies are private healthcare ambulatory pharmaceutical establishments, which are dedicated to selling allopathic, herbal, homeopathic products, cosmetics, personal hygiene products, medical devices, and dietary supplements. In 2003 , there were 14,208 drugstores and around 1,000 pharmacies; however, by 2014 this number had increased to more than 20,000, mainly due to the expanding of drugstores. The ambulatory pharmacy staff is frequently the first healthcare provider with whom a patient comes into contact before using a medication, principally because the drugstores and pharmacies are more accessible. In addition, in Colombia the pharmacy staff can work in these establishments with any of the following training levels: university formation (professional and technician) and without university formation (technical/auxiliary or with and without a certificate).

To our knowledge, there is no information available regarding studies related to the competencies that pharmacy staff should have in the provision of ambulatory pharmacy services: dispensing, health education, and pharmacovigilance of drugs with fiscalized substances. In that regard, the impact of continuing education in pharmacy staff has been described, focusing efforts on promoting the rational use of medicines, including opioids, antidepressants, 
anxiolytics, and even preventing these medications' abuse [10-14]. In this context, the objective of this study was to evaluate the effectiveness of a continuing education program to improve pharmacy staff competencies to enhance the ambulatory pharmacy services: dispensation, health education, and pharmacovigilance of drugs with fiscalized substances.

\section{Ethics approval}

This study was approved by the Ethics Committee of the National School of Public Health at the University of Antioquia, Colombia, at the 123rd session. It was conducted following the principles of the Declaration of Helsinki. All participants, pharmacy staff, patients (or caregivers), and simulated patients completed informed consent before starting the study.

\section{Methods}

The study protocol was registered and published on ClinicalTrials.gov (identifier: NCT03388567) and the study methods were described in detail in a previous publication of the study protocol [15].

Study design and setting: This multicenter, prospective, parallel-group, cluster-randomized, controlled clinical trial was conducted in Medellin and the Metropolitan Area (Colombia) drugstores and pharmacies (Figure 1). We developed a 12-month intervention delivery and follow-up (September 2018 to September 2019). Drugstores and pharmacies (the clusters) were randomized at a 1:1 ratio to enroll in either the intervention or control group. The geography zone (neighborhoods) was randomized stratified. For the method design, the Consolidated Standards of Reporting Trials (CONSORT) recommendations were followed.

Study population and recruitment: We identified the drugstores and pharmacies in a cross-sectional epidemiological study on utilizing drugs with fiscalized substances in 2016 [16]. We invited the pharmacy staff (professional, technician, technical/auxiliary or with and without a certificate) of 700 drugstores and pharmacies to participate in the study. The trial recruited at least one pharmacy staff member from each drugstore or pharmacy.

Sample size: The continuing education program was expected to improve the pharmacy staff competencies in the intervention group by at least $30 \%$ and in the control group by $15 \%$. Considering the educational intervention findings rises in $37 \%$ of the competencies [17]. Therefore, with a confidence level of $95 \%$ and a power of $80 \%$, it was calculated at least 121 drugstores and pharmacies in each group. The sample was increased by $10 \%$ to cover losses to follow-up, increasing the sensitivity; the final selection size was 135 drugstores and pharmacies, for each group.

Allocation and blinding: Group allocation (intervention group or the control group) was blinded. Blinding of pharmacy staff was not possible because of the nature of the intervention. Patients and caregivers were blinded because they did not receive the given details of the intervention.

Intervention: Continuing education program: The continuing education program was made with different and independents actions executed transversely during their implementation and follow-up (12 months: September 2018 to September 2019).

- Web-based social networking sites and access to a virtual classroom: The Web-based social networking site's access and interactivity were continuous 24 hours a day, 7 days a week. The pharmacy staff accessed from personal computers and mobile touch screen devices, sharing their status with the community to establish communication with others.

- Virtual course: The virtual course was designed using Moodle 3.3.2+, and composed of 7 modules: 1) Pharmaceutical terminology and basic pharmacology, 2) Pharmaceutical legislation, 3) Administrative and technical activities related to supply of medicines in pharmacies, 4) Communication and health education from the pharmacy, 5) Good practices of dispensation and correct use of drugs, 6) Pharmacovigilance from the pharmacy, and 7) Pharmaceutical actuation of some common diseases in the pharmacy and, in which drugs with fiscalized substances are used (depression, anxiety, sleep disorders, and pain management). Each module's study time required an average of 20 hours of study (10 hours synchronous and 10 hours asynchronous), for a total of 140 hours of virtual course.

- Drug information and dispensing system: The software had three main components: dispensing, pharmacovigilance, and pharmaceutical care. The pharmacy staff entered patient personal information, health problems, and information about the drugs. The general information for the utilization of proper drugs with fiscalized substances that patients use could be accessed. The pharmacy staff could refer (reference) the patient to the principal investigator of the study (professional pharmacist) to conduct counseling, education, or pharmaceutical care.

- Pharmacy staff training: All the intervention group pharmacist staff were invited to participate in five face-to-face training to complement the virtual course contents. Each session was last 4 hours, for a total of 20 hours of face-to-face training.

Control group: Pharmacy staff in the control group received during the follow-up time written material on the correct use of complex dosage forms.

Strategies to improve adherence to protocol: The pharmacy staff received phone calls from one of the researchers to encourage compliance with the protocol, solve questions, and provide technical support. Each module of the virtual course completed by pharmacy staff was certificated.

Outcomes. Pharmacy staff competencies were assessed using two self-applied questionnaires: One questionnaire of 50 multiple-choice questions for the knowledge and the skills and attitudes, and another questionnaire of 100 questions with four possible options: never, sometimes, usually, or always. The measurements were performed baseline (T0) before the intervention and 12 months (1-year) after completing the follow-up (T12). Additionally, the simulated patient technique was used to evaluate the pharmacy staff's skills and attitudes in the dispensation and the information provide for the correct use of tramadol (drugs with fiscalized substance). 
Simulated patient technique: Simulated patient methodology is an effective tool or method that evaluates aspects in providing health care services to patients and is provided by pharmacy staff in actual practice. This research methodology has demonstrated its validity and reliability in investigating the practice of healthcare pharmacy [18]. Twenty simulated patients were trained to be representing and act coherently and accurately predetermined disease and treatment, specifically back pain and use of tramadol by medical prescription. The simulated patients signed informed consent to guarantee the confidentiality of the information collected. The pharmacy staff did not know at any time that the patient was simulated. The indicators evaluated were the average time of dispensing, the availability of tramadol stocks, the specific process for a first dispensing, the use of tools and materials to provide information, important safety information (absolute contraindications and most frequent adverse drug reactions) and recommendations for correct use, including the importance of adherence therapy. Additionally, following the Good Dispensing Practices [19], the simulated patients were trained to evaluate the dispensing process at the end of each visit as good, regular, or bad [20].

Statistical methods: Baseline and demographic characteristics were analyzed descriptively.

For between-group comparisons, the Chi-square test (or the Fisher exact test when appropriate) was conducted for comparisons categorical variables, and continuous variables used the independent sample t-test or the Mann-Whitney U test. We used the McNemar test for pre-post analyses to evaluate the difference in the competency's questionnaire of skills/attitudes and the Wilcoxon test for the knowledge questionnaire scores. All statistical tests were computed using the Statistical Package for the Social Sciences (version 23; SPSS, Chicago, III., USA) with significance defined as a p<0.05.

\section{Results}

\section{Baseline characteristics.}

The sample consisted of 305 drugstores and pharmacies (153 in the intervention group and 152 in the control group). The $83 \%$ (253) were of low-medium socioeconomic level. Of the 750 pharmacy staff invited, $88 \%$ (659) agreed to participate; a total of 379 pharmacy staff were assigned to the intervention group and 280 to the control group. The mean age of participants was 35.6 years (SD 11.7), 65.3\% (430) were women, the mean work experience as pharmacy staff was 10.9 years (SD 10.14), and $70 \%$ (462) were not have university formation (technical/auxiliaries with and without a certificate). No differences were found in the sociodemographic variables of establishments and pharmacy staff between the two groups (Table 1).

The 100 skills and attitudes performance indicators evaluated were categorized into 25 different competencies. In 96\% (24) of the competencies, no statistically significant differences were found between the study groups (Table 2). In $86 \%$ (43) of the 50 knowledge questions, the correct answered were not statistically different between the control and intervention groups (Table 3).

\section{Effect of continuing education program}

Overall, 56.4\% (372) pharmacy staff completed the continuing education program and skills, attitudes, and knowledge questionnaires (Table 2). The pharmacy staff's skills, attitudes, and knowledge scores at post-intervention were statistically significantly higher than the pre-intervention, and the intervention group had higher scores than the control group. After the intervention, the skills and attitudes in the intervention group improved by $88 \%$ (22), and knowledge rose in six of the seven blocks of the topics developed. Although, there was an increase in knowledge in the control group, it was not statistically significant.

During the application of the simulated patient technique, the simulated patients were not recognized or identified by the pharmacy staff; both into and between groups there were no statistically significant differences among the final and initial figures of the dispensing criteria evaluated (Table 4); and among the 585-total dispensations of tramadol, $98 \%$ (575) was assessed as bad.

\section{Discussion}

This is the first controlled and multicenter trial that evaluates a continuing education program's effectiveness to improve ambulatory pharmacy staff's competencies in providing dispensing, health education, and pharmacovigilance services of drugs with fiscalized substances (including controlled drugs). The ambulatory pharmacy staff plays an essential role in improving pharmacotherapy and patient outcomes, promoting rational use of medicines and reducing healthcare costs [21]. The implementation of a continuing education program significantly improved learner outcomes, with a significant difference between the intervention group and the control group.

The identification and initial characterization of the pharmacy staff's training and continuing education needs of the same population is a strength of the study. This characterization identified the pharmacy staff's perception of the risk of fiscalized drugs and the lack of technical processes and care services in drugstores and pharmacies [16]. Also, another strength of this study was the design, construction, and evaluation of different tools supported by ICTs: the social network-like web platform, the virtual course, and the system of information and dispensing of drugs. It is important to denote that studies that combine such strategies into the same intervention were not found. In addition, it is the first web platform-type social network aimed exclusively at ambulatory pharmacy staff and a virtual course focused on updating the correct use of drugs with fiscalized substances.

The participation of 659 pharmacy staff who worked in 305 different drugstores and pharmacies gives this study the characteristics of a multicenter study. Although the possible variability of the interventions becomes a strength, due to which is very much in line with the actuality of ambulatory practice. However, only $30 \%$ of the personnel who work in these establishments has university formation (professional or technician degree). This supports the need for this type of experimental study and continues looking for continuing education strategies for all pharmacy staff. The remaining $70 \%$ of pharmacy staff was technical/auxiliary or with and without a certificate (Table 1). Another study carried out in Bogotá in 2005 [22] evaluated the profile and practices of drug dispensers in drugstores and pharmacies, reporting that about $67 \%$ of pharmacy staff did not have professional or technician degree, and that dispensing was

Page $4 / 11$ 
carried out inadequately in $55 \%$ of the cases. Therefore, these results show a critical scenery mainly characterized by a pharmacy staff near to $70 \%$ without university education and training necessary to work as a pharmacist in pharmacies and drugstores.

Another strength of the study was the complementation of the virtual educational process with face-to-face training. To our knowledge, this is the study with the highest number of virtual and face-to-face training hours during the 12 months of follow-up. The total time was 160 hours: 140 hours of virtual intervention and 20 hours of face-to-face training. In this context, the most similar study to this study was an analytical observational study of a virtual educational program with an intervention time of 120 hours, which evaluated acquiring knowledge, skills, and performance attitudes (self-informed changes and considered in standard practice) [23].

Some results have showed that self-directed learning, continuing education programs, and other traditional continuing education activities alone do not facilitate change in practice [24-26]. Similarly, the results of our study regarding the simulated patient technique did no evidence improvements during tramadol dispensing (Table 4). Despite substantial increases both in knowledge as in skills and practices self-reported by the pharmacy staff, these improvements were not reflected in dispensing, so pharmacy staff showed limitations both in dispensing and providing advice and support for the correct use of tramadol. These results can be used to generate future intervention studies focused on the effect of improving skills and attitudes in dispensing and providing information for correct use of drugs. Also, these findings could show that pharmacy staff needs both formation additional and training continuous/sustainable in pharmacy oriented to improve dispensing and providing advice and support for the correct use of medications [9].

\section{Limitations and potential bias}

Although the simulated patient technique has shown validity and reliability in pharmacy practice research [18], the lack of audio or video record could cause potential bias regarding information and assessment carried out by simulated patients. However, this limitation could be minimized by training of these persons. Also, it was sought to ensure that all simulated patients completed the evaluation questionnaire immediately after each visit with the principal investigator, who was the same person who trained and transported the simulated patients in all visits to the pharmacies.

\section{Conclusion}

Continuing education program using virtual tools plus additional personalized training is a feasible and practical educational intervention strategy for pharmacy staff showing positive results in the pharmacy staff's competencies (assessed knowledge and self-reported skills and attitudes); however, skills and attitudes to dispensing and providing advice and support for the correct use of tramadol were no improved. The educational intervention, integrated with a social network-type web platform, a virtual course for updating pharmacotherapeutic, and an information system for dispensing of drugs added to a personalized training focused on the proper utilization of drugs with fiscalized substances could be enhanced ambulatory pharmacy services, such as dispensing, health education and pharmacovigilance.

\section{Declarations}

\section{Acknowledgments}

The authors thank the participating pharmacy staff and simulated patients.

\section{Funding}

The Pharmaceutical Promotion and Prevention Group received financial support from the Committee for Development Research and the sustainability program (2018-2019) of the University of Antioquia. Also, this research was financed partially by Laproff Laboratories, providing the multimedia resources used in this study.

\section{Conflicts of Interest}

The authors declare no conflict of interest.

\section{References}

1. Ceballos M, Amariles P. Needs and opportunities for outpatient pharmacies in Colombia: The case of continuing education programs for pharmacists. Vitae. 2017;24(1):10-11.

2. Svetlana S, Ivana T, Tatjana C, Duskana K, Ian B. Evaluation of Competences at the Community Pharmacy Settings. Indian J Pharm Educ Res. 2014;48(4):22-30.

3. Schostak J, Davis M, Hanson J, Schostak J, Brown T, Driscoll P, et al. Effectiveness of continuing professional development project: A summary of findings. Med Teach. 2010;32(7):586-92.

4. Fisher JE, Zhang Y, Sketris I, Johnston G, Burge F. The effect of an educational intervention on meperidine use in Nova Scotia, Canada: a time series analysis. Pharmacoepidemiol Drug Saf. 2012;21(2):177-83.

5. Sullivan MD, Gaster B, Russo J, Bowlby L, Rocco N, Sinex N, et al. Randomized Trial of Web-based Training About Opioid Therapy for Chronic Pain. Clin J Pain. 2010;26(6):512-7.

6. Kahan M, Wilson L, Wenghofer EF, Srivastava A, Resnick A, Janecek E, et al. Pharmacists' experiences with dispensing opioids: provincial survey. Can Fam Physician. 2011;57(11):e448-54. 
7. Wilsey BL, Fishman SM, Casamalhuapa C, Singh N. Computerized progress notes for chronic pain patients receiving opioids; the Prescription Opioid Documentation System (PODS). Pain Med. 2010;11(11):1707-17.

8. Rigg KK, March SJ, Inciardi JA. Prescription Drug Abuse \& Diversion: Role of the Pain Clinic. J Drug Issues. 2010;40(3):681-702.

9. Amariles P, Ceballos M, González-Giraldo C. Primary health care policy and vision for community pharmacy and pharmacists in Colombia. Pharm Pract (Granada). 2020;18(4):1-7.

10. Kouladjian L, Chen TF, Gnjidic D, Hilmer SN. Education and Assessment of Pharmacists on the Use of the Drug Burden Index in Older Adults Using a Continuing Professional Development Education Method. Am J Pharm Educ. 2016;80(4):63.

11. Buxton EC, De Muth JE. Pharmacists' perceptions of a live continuing education program comparing distance learning versus local learning. Res Social Adm Pharm. 2013;9(2):230-5.

12. Walters $C$, Raymont A, Galea S, Wheeler A. Evaluation of online training for the provision of opioid substitution treatment by community pharmacists in New Zealand. Drug Alcohol Rev. 2012;31(7):903-10.

13. Palmer E, Hart S, Freeman PR. Development and delivery of a pharmacist training program to increase naloxone access in Kentucky. J Am Pharm Assoc (2003). 2017;57(2S):S118-22.

14. Wheeler A, Fowler J, Hattingh L. Using an intervention mapping framework to develop an online mental health continuing education program for pharmacy staff. J Contin Educ Health Prof. 2013;33(4):258-66.

15. Ceballos M, Salazar-Ospina A, Sabater-Hernández D, Amariles P. Evaluation of the effects of a drug with fiscalized substance dispensation, health education, and pharmacovigilance continuing education program in Colombia drugstores and drugstores/pharmacies: study protocol of a multicenter, cluster-randomized control. Trials. 2020;21(1):545-59.

16. Ceballos M, Giraldo JA, Marín VH, Amariles P. Characterization of aspects related to the use of controlled drugs in Drugstores and pharmacies-drugstores in Medellin and the Metropolitan Area. Rev. Univ. Ind. Santander. Salud. 2018;50(1):27-36.

17. García Corpas JP, Ocaña Arenas A, González García L, López Domínguez E, García Jiménez E, Amariles P, et al. Variación del conocimiento al asistir a un taller de asma para farmacéuticos comunitarios. Pharm Pract. 2006;4(3):139-42.

18. Xu T, de Almeida Neto AC, Moles RJ. A systematic review of simulated-patient methods used in community pharmacy to assess the provision of nonprescription medicines. Int J Pharm Pract. 2012;20(5):307-19.

19. World Health Organization. Chapter 30: Ensuring good dispensing practices). Management Science for Health - Part II: Pharmaceutical Management. 2012. Available at: https://www.msh.org/sites/msh.org/files/mds3-ch30-dispensing-mar2012.pdf. Accessed February 25, 2021.

20. Ceballos M, Llano Y, Salazar-Ospina A, Madrigal-Cadavid J, Pino D, Amariles P. ARTICLE IN PRESS. Skills and practices of pharmacy staff for the dispensation of drugs with controlled substances in pharmacies and drugstores. Rev Saude Public.

21. Nkansah N, Mostovetsky O, Yu C, Chheng T, Beney J, Bond CM, et al. Effect of outpatient pharmacists' non-dispensing roles on patient outcomes and prescribing patterns. Cochrane Database Syst Rev. 2010;2010(7):CD000336.

22. Vacca C, Orozco J, Figueras A, Capellà D. Assessment of Risks Related to Medicine Dispensing by Nonprofessionals in Colombia: Clinical Case Simulations. Ann Pharmacother. 2005;39(3):527-32.

23. Moczygemba LR, Pierce AL, Dang A, Emberley P, Czar MJ, Matzke GR. The ADAPT online education program: A tool for practicing pharmacists delivering patient-centered care. J Am Pharm Assoc (2003). 2017;57(5):601-7.

24. McConnell KJ, Newlon CL, Delate T. The impact of continuing professional development versus traditional continuing pharmacy education on pharmacy practice. Ann Pharmacother. 2010;44(10):1585-95.

25. Davis D, O'Brien MAT, Freemantle N, Wolf FM, Mazmanian P, Taylor-Vaisey A. Impact of formal continuing medical education: Do conferences, workshops, rounds, and other traditional continuing education activities change physician behavior or health care outcomes? JAMA; 1999;282(9):867-74.

26. Ceballos M, Madrigal-Cadavid J, Amariles P. ARTICLE IN PRESS. Educational programs and interventions offered to pharmacy staff to improve the delivery of pharmaceutical assistance services: A structured review. Univ. Ind. Santander. Salud.

\section{Tables}

Tabla 1. Pharmacy staff sociodemographic characteristics. 


\begin{tabular}{|c|c|c|c|c|}
\hline & $\begin{array}{l}\text { Total } \\
(n=659)\end{array}$ & $\begin{array}{l}\text { Intervention } \\
(n=379)\end{array}$ & $\begin{array}{l}\text { Control } \\
(n=280)\end{array}$ & P-value \\
\hline \multicolumn{5}{|l|}{ Gender, n (\%) } \\
\hline Female & $430(65.3)$ & $244(64.4)$ & $186(66.4)$ & \multirow[t]{2}{*}{0.585} \\
\hline Male & $229(34.7)$ & $135(35.6)$ & $94(33.6)$ & \\
\hline Age, mean (SD) & $35.6(11.7)$ & $35.1(11.6)$ & $36.3(11.9)$ & 0.191 \\
\hline \multicolumn{5}{|l|}{ Categories by age group, $\mathrm{n}(\%)$} \\
\hline 18 to 24 & $127(19.3)$ & $79(20.8)$ & $48(17.1)$ & \multirow[t]{5}{*}{0,620} \\
\hline 25 to 34 & $218(33.1)$ & $127(33.5)$ & $91(32.5)$ & \\
\hline 35 to 44 & $148(22.5)$ & $83(21.9)$ & $65(23.2)$ & \\
\hline 45 to 54 & $112(17)$ & $63(16.6)$ & 49 (17.5) & \\
\hline 55 to 74 & $54(8.2)$ & $27(7.1)$ & $27(9.6)$ & \\
\hline \multicolumn{5}{|l|}{ Pharmacy role, $\mathrm{n}(\%)$} \\
\hline Employee & $457(69.3)$ & $272(71.8)$ & $185(66.1)$ & \multirow[t]{2}{*}{0.117} \\
\hline Owner & $202(30.7)$ & $107(28.2)$ & $95(33.9)$ & \\
\hline \multicolumn{5}{|l|}{ Educational level, n (\%) } \\
\hline University formation: professional (pharmacist) or technician degree & $197(30)$ & $116(30.6)$ & $81(29)$ & \multirow[t]{2}{*}{0.667} \\
\hline Without university formation: Technical/auxiliary or with and without a certificate & $462(70)$ & $263(69.4)$ & $199(71)$ & \\
\hline Working experience time (years), average (SD) & $10.9(10.14)$ & $10.3(9.62)$ & $11.7(10.76)$ & 0.207 \\
\hline Hours a day worked, average (SD) & $8.9(2.2)$ & $8.7(2.2)$ & $9.1(2.5)$ & 0.065 \\
\hline Time working at PE (years), average (SD) & $4.74(60.4)$ & $4.13(5.09)$ & $5.56(7.04)$ & 0.067 \\
\hline Lives in the same neighborhood of PE, $n$ (\%) & $289(43.9)$ & $171(45.1)$ & $118(42.1)$ & 0.475 \\
\hline Continuing education in life, $n(\%)$ & $149(22.6)$ & $94(24.5)$ & $55(19.6)$ & 0.118 \\
\hline Continuing education last year, $n$ (\%) & $208(31.6)$ & $122(32.2)$ & $86(30.7)$ & 0.735 \\
\hline
\end{tabular}

PE: Pharmaceutical establishment; SD: Standard deviation.

Table 2. Evaluation of pharmacy staff competencies (skills and attitudes). 


\begin{tabular}{|c|c|c|c|c|c|c|c|c|c|c|c|c|}
\hline & & \multicolumn{3}{|c|}{ Initial measurement } & \multirow{3}{*}{$\begin{array}{l}\text { P- } \\
\text { value* }\end{array}$} & \multicolumn{4}{|c|}{ Final measurement } & \multicolumn{2}{|c|}{$\begin{array}{l}\text { Total } \\
\text { (before and after) }\end{array}$} & $\begin{array}{l}\text { Intervention } \\
\text { (before and }\end{array}$ \\
\hline & & $\begin{array}{l}\text { Total } \\
(n=659)\end{array}$ & $\begin{array}{l}\text { Intervention } \\
(n=379)\end{array}$ & $\begin{array}{l}\text { Control } \\
(n=280)\end{array}$ & & $\begin{array}{l}\text { Total } \\
(n=372)\end{array}$ & $\begin{array}{l}\text { Intervention } \\
(n=193)\end{array}$ & $\begin{array}{l}\text { Control } \\
(n=179)\end{array}$ & $\begin{array}{l}\text { P- } \\
\text { value* }\end{array}$ & $\begin{array}{l}\text { Dif. } \\
\text { Median }\end{array}$ & $\begin{array}{l}\text { P- } \\
\text { Value** }\end{array}$ & $\begin{array}{l}\text { Dif. } \\
\text { Medium }\end{array}$ \\
\hline & & $\begin{array}{l}\text { (Median } \\
\text { - IQ) }\end{array}$ & $\begin{array}{l}\text { (Median - } \\
\text { IQ) }\end{array}$ & $\begin{array}{l}\text { (Median } \\
- \text { IQ) }\end{array}$ & & $\begin{array}{l}\text { (Median } \\
\text { - IQ) }\end{array}$ & $\begin{array}{l}\text { (Median - } \\
\text { IQ) }\end{array}$ & $\begin{array}{l}\text { (Median } \\
\text { - IQ) }\end{array}$ & & & & \\
\hline & $\begin{array}{l}\text { Domain } 1 . \\
\text { Provision of } \\
\text { patient care. }\end{array}$ & & & & & & & & & & & \\
\hline 1 & $\begin{array}{l}\text { Initial contact } \\
\text { with the patient }\end{array}$ & $\begin{array}{l}2.9(2.6- \\
3.3)\end{array}$ & $\begin{array}{l}2.9(2.6- \\
3.1)\end{array}$ & $\begin{array}{l}3(2.5- \\
3.4)\end{array}$ & 0.089 & $\begin{array}{l}3.3(2.9- \\
3.6)\end{array}$ & $3.4(3-3.6)$ & $\begin{array}{l}3.1(2.8- \\
3.5)\end{array}$ & 0.002 & 0.4 & 0.000 & 0.5 \\
\hline 2 & $\begin{array}{l}\text { Prescription } \\
\text { (medical } \\
\text { formula) }\end{array}$ & $\begin{array}{l}3.8(3.3- \\
4)\end{array}$ & $3.8(3.3-4)$ & $\begin{array}{l}3.8 \\
(3.15-4)\end{array}$ & 0.243 & $\begin{array}{l}4(3.5- \\
4)\end{array}$ & $4(3.8-4)$ & $\begin{array}{l}4(3.5- \\
4)\end{array}$ & 0.060 & 0.2 & 0.000 & 0.2 \\
\hline 3 & $\begin{array}{l}\text { Need for patient } \\
\text { medications }\end{array}$ & $\begin{array}{l}3.5(3- \\
4)\end{array}$ & $3.5(3-4)$ & $\begin{array}{l}3.5(3- \\
4)\end{array}$ & 0.518 & $\begin{array}{l}3.5(3- \\
4)\end{array}$ & $3.5(3-4)$ & $\begin{array}{l}3.5(3- \\
4)\end{array}$ & 0.616 & 0.0 & 0.000 & 0.0 \\
\hline 4 & $\begin{array}{l}\text { Drug } \\
\text { reconciliation }\end{array}$ & $\begin{array}{l}2.5(2- \\
3)\end{array}$ & $2.5(2-3)$ & $\begin{array}{l}2.5(2- \\
3)\end{array}$ & 0.149 & $\begin{array}{l}3(2.5- \\
4)\end{array}$ & $3(2.5-4)$ & $\begin{array}{l}3(2.5- \\
3.5)\end{array}$ & 0.196 & 0.5 & 0.000 & 0.5 \\
\hline 5 & $\begin{array}{l}\text { Supply of } \\
\text { medicines }\end{array}$ & $\begin{array}{l}3.8(3.5- \\
4)\end{array}$ & $3.8(3.5-4)$ & $\begin{array}{l}4(3.5- \\
4)\end{array}$ & 0.087 & $\begin{array}{l}4(3.8- \\
4)\end{array}$ & $4(3.8-4)$ & $\begin{array}{l}4(3.8- \\
4)\end{array}$ & 0.199 & 0.2 & 0.000 & 0.2 \\
\hline 6 & $\begin{array}{l}\text { Using guides } \\
\text { and protocols }\end{array}$ & $3(3-4)$ & $2.5(3-4)$ & $3(3-4)$ & 0.019 & $4(3-4)$ & $3.5(3-4)$ & $3(3-4)$ & 0.741 & 1.0 & 0.000 & 0.0 \\
\hline 7 & $\begin{array}{l}\text { Drug } \\
\text { specifications }\end{array}$ & $\begin{array}{l}3.6(3- \\
3.9)\end{array}$ & $3.4(3-3.9)$ & $\begin{array}{l}3.65(3- \\
3.9)\end{array}$ & 0.158 & $\begin{array}{l}3.9(3.4- \\
4)\end{array}$ & $3.9(3.6-4)$ & $\begin{array}{l}3.7(3.3- \\
4)\end{array}$ & 0.063 & 0.3 & 0.000 & 0.5 \\
\hline 8 & $\begin{array}{l}\text { Drug } \\
\text { interactions }\end{array}$ & $3(2-3)$ & $3(2-3)$ & $3(2-3)$ & 0.654 & $3(2-4)$ & $3(2-4)$ & $3(2-4)$ & 0.448 & 0.0 & 0.000 & 0.0 \\
\hline 9 & $\begin{array}{l}\text { Drug } \\
\text { information and } \\
\text { patient } \\
\text { education }\end{array}$ & $\begin{array}{l}2.5(2.2- \\
2.8)\end{array}$ & $\begin{array}{l}2.5(2.2- \\
2.8)\end{array}$ & $\begin{array}{l}2.5(2.1- \\
2.8)\end{array}$ & 0.238 & $\begin{array}{l}2.8(2.5- \\
3.2)\end{array}$ & $\begin{array}{l}2.9(2.6- \\
3.3)\end{array}$ & $\begin{array}{l}2.6(2.3- \\
3.1)\end{array}$ & 0.000 & 0.3 & 0.000 & 0.4 \\
\hline 10 & $\begin{array}{l}\text { Identifying drug- } \\
\text { related } \\
\text { problems }\end{array}$ & $3(3-4)$ & $3(2-4)$ & $3(3-4)$ & 0.335 & $4(3-4)$ & $4(3-4)$ & $4(3-4)$ & 0.238 & 1.0 & 0.000 & 1.0 \\
\hline 11 & Patient care & $2(2-3)$ & $2(2-3)$ & $2(2-3)$ & 0.730 & $\begin{array}{l}3(2- \\
3.5)\end{array}$ & $3(2.5-4)$ & $2.5(2-$ & 0.000 & 1.0 & 0.000 & 1.0 \\
\hline \multirow[t]{2}{*}{12} & $\begin{array}{l}\text { Results } \\
\text { assessment }\end{array}$ & $1(1-2)$ & $1(1-2)$ & $1(1-2)$ & 0.555 & $\begin{array}{l}2(1- \\
2.5)\end{array}$ & $2(1-3)$ & $\begin{array}{l}1.5(1- \\
2.5)\end{array}$ & 0.000 & 1.0 & 0.000 & 1.0 \\
\hline & $\begin{array}{l}\text { Domain } 2 . \\
\text { Personal }\end{array}$ & & & & & & & & & & & \\
\hline 13 & $\begin{array}{l}\text { Personal } \\
\text { organization }\end{array}$ & $\begin{array}{l}3.7(3.3- \\
4)\end{array}$ & $3.7(3.3-4)$ & $\begin{array}{l}3.7(3.3- \\
4)\end{array}$ & 0.208 & $\begin{array}{l}3.8(3.5- \\
4)\end{array}$ & $3.8(3.5-4)$ & $\begin{array}{l}3.8(3.5- \\
4)\end{array}$ & 0.686 & 0.1 & 0.001 & 0.1 \\
\hline 14 & $\begin{array}{l}\text { Effective } \\
\text { communication } \\
\text { skills }\end{array}$ & $\begin{array}{l}3.7(3- \\
4)\end{array}$ & $3.5(3-4)$ & $\begin{array}{l}3.7(3.2- \\
4)\end{array}$ & 0.154 & $\begin{array}{l}3.8(3.3- \\
4)\end{array}$ & $3.8(3.3-4)$ & $\begin{array}{l}3.7(3.3- \\
4)\end{array}$ & 0.224 & 0.1 & 0.000 & 0.3 \\
\hline 15 & Team & $\begin{array}{l}3.8(3.4- \\
4)\end{array}$ & $3.8(3.4-4)$ & $\begin{array}{l}3.8(3.6- \\
4)\end{array}$ & 0.114 & $\begin{array}{l}3.8(3.6- \\
4)\end{array}$ & $4(3.6-4)$ & $\begin{array}{l}3.8(3.6- \\
4)\end{array}$ & 0.197 & 0.0 & 0.001 & 0.2 \\
\hline \multirow[t]{2}{*}{16} & Professionalism & $\begin{array}{l}3.4(3.1- \\
3.8)\end{array}$ & $\begin{array}{l}3.4(3.1- \\
3.8)\end{array}$ & $\begin{array}{l}3.5(3.2- \\
3.8)\end{array}$ & 0.480 & $\begin{array}{l}3.6(3.3- \\
3.9)\end{array}$ & $\begin{array}{l}3.7(3.5- \\
3.9)\end{array}$ & $\begin{array}{l}3.6(3.2- \\
3.8)\end{array}$ & 0.000 & 0.2 & 0.000 & 0.3 \\
\hline & $\begin{array}{l}\text { Domain } 3 . \\
\text { Troubleshooting }\end{array}$ & & & & & & & & & & & \\
\hline 17 & $\begin{array}{l}\text { On the } \\
\text { information }\end{array}$ & $\begin{array}{l}3(2.3- \\
3.7)\end{array}$ & $3(2.3-3.7)$ & $\begin{array}{l}3(2.3- \\
3.7)\end{array}$ & 0.218 & $\begin{array}{l}3.3(3- \\
4)\end{array}$ & $3.7(3-4)$ & $\begin{array}{l}3.3(2.7- \\
3.7)\end{array}$ & 0.000 & 0.3 & 0.000 & 0.7 \\
\hline 18 & Knowledge & $\begin{array}{l}3(2.5- \\
3.5)\end{array}$ & $3(2.5-3.5)$ & $\begin{array}{l}3(2.5- \\
3.5)\end{array}$ & 0.059 & $3(3-4)$ & $3(3-4)$ & $\begin{array}{l}3(2.5- \\
4)\end{array}$ & 0.264 & 0.0 & 0.000 & 0.0 \\
\hline 19 & $\begin{array}{l}\text { Analysis of } \\
\text { information }\end{array}$ & $\begin{array}{l}2.5(2.2- \\
3.2)\end{array}$ & $2.5(2-3.2)$ & $\begin{array}{l}2.6(2.2- \\
3)\end{array}$ & 0.431 & $\begin{array}{l}3(2.5- \\
3.5)\end{array}$ & $3(2.7-3.7)$ & $\begin{array}{l}2.8(2.3- \\
3.3)\end{array}$ & 0.001 & 0.5 & 0.000 & 0.5 \\
\hline 20 & $\begin{array}{l}\text { Provides } \\
\text { information }\end{array}$ & $\begin{array}{l}3.7(3.7- \\
4)\end{array}$ & $3.7(3.7-4)$ & $\begin{array}{l}3.7(3.7- \\
4)\end{array}$ & 0.717 & $\begin{array}{l}4(3.3- \\
4)\end{array}$ & $4(3.7-4)$ & $\begin{array}{l}4(3.3- \\
4)\end{array}$ & 0.000 & 0.3 & 0.000 & 0.3 \\
\hline 21 & Tracking & $2(2-3)$ & $2(2-3)$ & $2(2-3)$ & 0.667 & $3(2-3)$ & $3(2-4)$ & $2(2-3)$ & 0.016 & 1.0 & 0.000 & 1.0 \\
\hline
\end{tabular}




\begin{tabular}{|c|c|c|c|c|c|c|c|c|c|c|c|c|c|}
\hline 22 & $\begin{array}{l}\text { Clinical } \\
\text { management } \\
\text { and pharmaco- } \\
\text { security }\end{array}$ & $\begin{array}{l}2.3(2- \\
3)\end{array}$ & $2.3(2-2.7)$ & $\begin{array}{l}2.5(2- \\
3)\end{array}$ & 0.257 & $\begin{array}{l}2.7(2- \\
3.3)\end{array}$ & $2.7(2-3.3)$ & $\begin{array}{l}2.7(2- \\
3.3)\end{array}$ & 0.837 & 0.4 & 0.000 & 0.4 & 1 \\
\hline 23 & $\begin{array}{l}\text { Provision of } \\
\text { service }\end{array}$ & $3(3-4)$ & $3(3-4)$ & $3(3-4)$ & 0.187 & $4(3-4)$ & $4(3-4)$ & $3(3-4)$ & 0.006 & 1.0 & 0.000 & 1.0 & 1 \\
\hline 24 & Acquisition & $\begin{array}{l}3.5(3.3- \\
4)\end{array}$ & $3.5(3.3-4)$ & $\begin{array}{l}3.8(3.3- \\
4)\end{array}$ & 0.161 & $\begin{array}{l}3.8(3.5- \\
4)\end{array}$ & $3.8(3.5-4)$ & $\begin{array}{l}3.8(3.3- \\
4)\end{array}$ & 0.258 & 0.3 & 0.003 & 0.3 & I \\
\hline 25 & $\begin{array}{l}\text { Satisfaction of } \\
\text { the services } \\
\text { offered }\end{array}$ & $\begin{array}{l}1.5(1- \\
2.5)\end{array}$ & $1.5(1-2.5)$ & $\begin{array}{l}1.5(1- \\
2.5)\end{array}$ & 0.256 & $\begin{array}{l}2.5(1.5- \\
3)\end{array}$ & $2.5(1.5-3)$ & $\begin{array}{l}2.5(1.5- \\
3)\end{array}$ & 0.740 & 1.0 & 0.000 & 1.0 & I \\
\hline
\end{tabular}

* Mann-Whitney U test; ** Wilcoxon test; IQ: Inter quarterly range.

Table 3. Evaluation of knowledge in pharmacy staff

\begin{tabular}{|c|c|c|c|c|c|c|c|c|}
\hline & \multicolumn{4}{|c|}{ Initial measurement } & \multicolumn{4}{|c|}{ Final measurement } \\
\hline & $\begin{array}{l}\text { Total } \\
(n=659)\end{array}$ & $\begin{array}{l}\text { Intervention } \\
(n=379)\end{array}$ & $\begin{array}{l}\text { Control } \\
(280)\end{array}$ & $\begin{array}{l}\text { P- } \\
\text { value* }\end{array}$ & $\begin{array}{l}\text { Total } \\
(n=372)\end{array}$ & $\begin{array}{l}\text { Intervention } \\
(\mathrm{n}=193)\end{array}$ & $\begin{array}{l}\text { Control } \\
(n=179)\end{array}$ & $\begin{array}{l}\text { P- } \\
\text { value* }\end{array}$ \\
\hline $\begin{array}{l}\text { Block 1: Basic pharmacology and pharmaceutical } \\
\text { terminology, } \mathrm{n}(\%)\end{array}$ & $\begin{array}{l}437 \\
(66.3)\end{array}$ & $261(68.9)$ & $\begin{array}{l}176 \\
(62.9)\end{array}$ & 0.107 & $\begin{array}{l}261 \\
(70.2)\end{array}$ & $148(76.7)$ & $\begin{array}{l}113 \\
(63.1)\end{array}$ & 0.004 \\
\hline Block 2: Pharmaceutical legislation, n (\%) & $\begin{array}{l}546 \\
(82.9)\end{array}$ & $324(85.5)$ & $\begin{array}{l}222 \\
(79.3)\end{array}$ & 0.037 & $\begin{array}{l}328 \\
(88.2)\end{array}$ & $182(94.3)$ & $\begin{array}{l}146 \\
(81.6)\end{array}$ & 0.000 \\
\hline $\begin{array}{l}\text { Block 3: Technical-administrative processes of the } \\
\text { drugstores, } \mathrm{n}(\%)\end{array}$ & $\begin{array}{l}243 \\
(36.9)\end{array}$ & $150(39.6)$ & $\begin{array}{l}93 \\
(33.2)\end{array}$ & 0.094 & $\begin{array}{l}223 \\
(59.9)\end{array}$ & $140(72.5)$ & $\begin{array}{l}83 \\
(46.4)\end{array}$ & 0.000 \\
\hline $\begin{array}{l}\text { Block 4: Information on the proper use of medicines and } \\
\text { health education, } \mathrm{n}(\%)\end{array}$ & $\begin{array}{l}355 \\
(53.9)\end{array}$ & $195(51.5)$ & $\begin{array}{l}160 \\
(57.1)\end{array}$ & 0.147 & $\begin{array}{l}243 \\
(65.3)\end{array}$ & $138(71.5)$ & $\begin{array}{l}105 \\
(58.7)\end{array}$ & 0.009 \\
\hline Block 5: Good Dispensation Practices, n (\%) & $\begin{array}{l}479 \\
(72.7)\end{array}$ & $285(75.2)$ & $\begin{array}{l}194 \\
(69.3)\end{array}$ & 0.092 & $\begin{array}{l}327 \\
(87.9)\end{array}$ & $183(94.8)$ & $\begin{array}{l}144 \\
(80.4)\end{array}$ & 0.000 \\
\hline Block 6: Pharmacovigilance of Pharmacies, n (\%) & $\begin{array}{l}114 \\
(17.3)\end{array}$ & $73(19.3)$ & $\begin{array}{l}41 \\
(14.6)\end{array}$ & 0.121 & $\begin{array}{l}124 \\
(33.3)\end{array}$ & $80(41.5)$ & $\begin{array}{l}44 \\
(24.6)\end{array}$ & 0.000 \\
\hline $\begin{array}{l}\text { Block 7: Pharmaceutical actuation in common diseases } \\
\text { using drugs with fiscalized substances, } \mathrm{n}(\%)\end{array}$ & $\begin{array}{l}560 \\
(85)\end{array}$ & $320(84.43)$ & $\begin{array}{l}228 \\
(81.4)\end{array}$ & 0.078 & $\begin{array}{l}345 \\
(92.7)\end{array}$ & $187(96.9)$ & $\begin{array}{l}158 \\
(88.3)\end{array}$ & 0.001 \\
\hline Total, n (\%) & $\begin{array}{l}305 \\
(46.3)\end{array}$ & $180(47.5)$ & $\begin{array}{l}125 \\
(44.6)\end{array}$ & 0.468 & $\begin{array}{l}266 \\
(71.5)\end{array}$ & $163(84.5)$ & $\begin{array}{l}103 \\
(57.5)\end{array}$ & 0.000 \\
\hline
\end{tabular}

\section{*Chi-squared test}

Table 4. Information about the drugs dispensed and the pharmacy staff's tools to provide information to the simulated patient. 


\begin{tabular}{|c|c|c|c|c|c|c|c|}
\hline & \multicolumn{3}{|c|}{ Initial figures } & \multicolumn{3}{|c|}{ Final figures } & \multirow{2}{*}{$\begin{array}{l}\text { P- } \\
\text { value* }\end{array}$} \\
\hline & $\begin{array}{l}\text { Total } \\
(n=296)\end{array}$ & $\begin{array}{l}\text { Intervention } \\
(n=150)\end{array}$ & $\begin{array}{l}\text { Control } \\
(n=146)\end{array}$ & $\begin{array}{l}\text { Total } \\
(\mathrm{n}=289)\end{array}$ & $\begin{array}{l}\text { Intervention } \\
(n=147)\end{array}$ & $\begin{array}{l}\text { Control } \\
(n=142)\end{array}$ & \\
\hline \multicolumn{8}{|l|}{ About the drug dispensed: } \\
\hline $\begin{array}{l}\text { Tramadol was properly dispensed according to prescribed dosage } \\
\text { form and concentration, } \mathrm{n}(\%)\end{array}$ & $\begin{array}{l}296 \\
(100)\end{array}$ & $150(100)$ & $\begin{array}{l}146 \\
(100)\end{array}$ & $\begin{array}{l}289 \\
(100)\end{array}$ & $147(100)$ & $\begin{array}{l}142 \\
(100)\end{array}$ & \\
\hline Pharmacy staff dispensed other drug different to tramadol, n (\%) & 0 & 0 & 0 & 0 & 0 & 0 & \\
\hline $\begin{array}{l}\text { Pharmacy staff actively provided information and then dispensed } \\
\text { the tramadol (the simulated patient did not have to ask any } \\
\text { questions), } \mathrm{n}(\%)\end{array}$ & $17(5.7)$ & $6(3.9)$ & $11(7.2)$ & $19(6.5)$ & $8(5.4)$ & $11(7.7)$ & 1.000 \\
\hline Tramadol was dispensed without informing the patient, $\mathrm{n}(\%)$ & $\begin{array}{l}279 \\
(94.3)\end{array}$ & $144(94.1)$ & $\begin{array}{l}135 \\
(88.8)\end{array}$ & $\begin{array}{l}270 \\
(93.4)\end{array}$ & $139(94.5)$ & $\begin{array}{l}131 \\
(92.2)\end{array}$ & 1.000 \\
\hline $\begin{array}{l}\text { Pharmacy staff recommended the use of other complementary over- } \\
\text { the-counter medicines (acetaminophen, naproxen, etc.), or non- } \\
\text { pharmacological measures for back pain, n (\%) }\end{array}$ & $1(0.3)$ & 0 & $1(0.7)$ & $1(0.3)$ & $1(0.7)$ & 0 & \\
\hline \multicolumn{8}{|l|}{ About using tools to provide information: } \\
\hline \multirow{3}{*}{$\begin{array}{l}\text { The information provided by the } \\
\text { pharmacy staff was: }\end{array}$} & $16(5.4)$ & $5(3.39$ & $11(7.5)$ & $18(6.2)$ & $7(4.7)$ & $10(7.0)$ & 1,000 \\
\hline & $9(3.0)$ & $3(2.0)$ & $6(4.1)$ & 0 & 0 & 0 & \\
\hline & $1(0.3)$ & $1(0.7)$ & 0 & $1(0.3)$ & $1(0.7)$ & 0 & 1,000 \\
\hline $\begin{array}{l}\text { The pharmacy staff gave me educational materials such as physical } \\
\text { flyers with information related to tramadol or back pain, } \mathrm{n}(\%)\end{array}$ & 0 & 0 & 0 & 0 & 0 & 0 & \\
\hline $\begin{array}{l}\text { The pharmacy staff assessed the satisfaction as a user/patient } \\
\text { (using some question format or orally), } n(\%)\end{array}$ & 0 & 0 & 0 & 0 & 0 & 0 & \\
\hline $\begin{array}{l}\text { The information provided by pharmacy staff was clear and accurate } \\
\text { at all times, } \mathrm{n}(\%)\end{array}$ & $8(2.7)$ & $4(2.7)$ & $4(2.79$ & $3(1.0)$ & $3(2.0)$ & 0 & 0.227 \\
\hline \multicolumn{8}{|l|}{ Pharmaceutical staff can provide information on the following precautions: } \\
\hline $\begin{array}{l}\text { Use of tramadol in women who are in the first trimester of pregnancy } \\
\text { suspect being pregnant or who are lactating, } n(\%)\end{array}$ & 0 & 0 & 0 & 0 & 0 & 0 & \\
\hline $\begin{array}{l}\text { Use in people driving vehicles (car, motorbike, bicycle), heavy or high } \\
\text { risk tools (construction), etc.); due to the possibility of dizziness and } \\
\text { drowsiness, n (\%) }\end{array}$ & $5(3.6)$ & $1(0.7)$ & $4(2.9)$ & $3(2.1)$ & $2(1.4)$ & $1(0.7)$ & 1.000 \\
\hline Tramadol can cause dependence or addiction; $\mathrm{n}(\%)$ & $1(0.7)$ & $1(0.7)$ & 0 & $1(0.7)$ & $1(0.7)$ & 0 & 1.000 \\
\hline Use of tramadol in people with seizures (epileptic seizures), n (\%) & 0 & 0 & 0 & 0 & 0 & 0 & \\
\hline $\begin{array}{l}\text { Use of tramadol with other medications that generate sedation and } \\
\text { hypnosis (medicines for depression, anxiety, sleep disorders), n (\%) }\end{array}$ & $3(2.1)$ & $1(0.7)$ & $2(1.4)$ & $1(0.7)$ & $1(0.7)$ & 0 & 0.625 \\
\hline Avoid alcohol consumption during treatment with tramadol, n (\%) & 0 & 0 & 0 & 0 & 0 & 0 & \\
\hline \multicolumn{8}{|c|}{ Pharmaceutical staff provided information on the following recommendations for use: } \\
\hline Dilute tramadol in a glass of water before ingesting, $n(\%)$ & $3(2.1)$ & 0 & $3(2.1)$ & $3(2.1)$ & $2(1.4)$ & $1(0.7)$ & 1.000 \\
\hline $\begin{array}{l}\text { Administer tramadol regardless of meals (before, during or after } \\
\text { eating), } \mathrm{n}(\%)\end{array}$ & $3(2.1)$ & $2(1.4)$ & $1(0.7)$ & $3(2.1)$ & $2(1.4)$ & $1(0.7)$ & 1.000 \\
\hline Do not use tramadol chronically, $\mathrm{n}(\%)$ & 0 & 0 & 0 & 0 & 0 & 0 & \\
\hline $\begin{array}{l}\text { Proper storage of tramadol at home, especially for the risk to my } \\
\text { family members and others, } n(\%)\end{array}$ & $4(2.8)$ & $2(1.4)$ & $2(1.4)$ & $1(0.7)$ & $1(0.7)$ & 0 & 1.000 \\
\hline The importance of adherence to treatment, $\mathrm{n}(\%)$ & $5(3.6)$ & $1(0.7)$ & $4(2.9)$ & $4(2.7)$ & $4(2.7)$ & 0 & 0.375 \\
\hline
\end{tabular}

\section{*Mcnemar test}

\section{Figures}




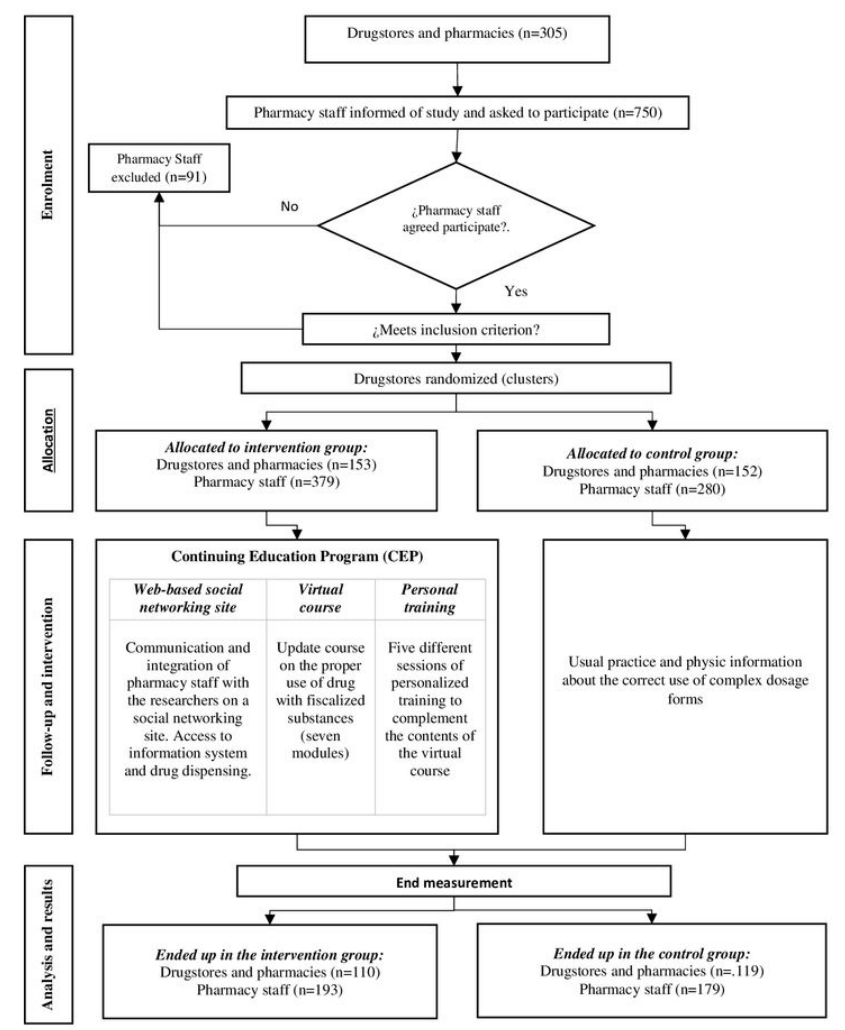

\section{Figure 1}

This multicenter, prospective, parallel-group, cluster-randomized, controlled clinical trial was conducted in Medellin and the Metropolitan Area (Colombia) drugstores and pharmacies 